\title{
The drilling of stratigraphic borehole Umiivik-1, Svartenhuk Halvø, West Greenland
}

Svartenhuk Halvø is one of the few areas onshore West Greenland where Upper Cretaceous and Lower Tertiary marine sediments are exposed (Fig. 1). Geological studies in the area have been made intermittently since the late 1930s but have intensified since 1990 as part of the Survey's overall effort to assess the petroleum potential of the Disko - Nuussuaq - Svartenhuk Halvø area and adjacent offshore basins. The search for evidence that a marine oil source rock of Cenomanian - Turonian age exists in West Greenland has been a preoccupation of the Survey since 1992 when it was first predicted that this was the most likely level for an oil source rock in the region (Chalmers et al., 1993). Oil-prone source rocks exist (in other locations) world-wide within the Cenomanian - Turonian succession associated with a global sea-level highstand. Recently, marine mudstones of this age with TOC (Total Organic Carbon) values of typically $8 \%$ or more and $\mathrm{Hy}$ drogen Indices of 300 to 500 have been described from the Sverdrup Basin on Ellesmere Island in the Canadian Arctic (Núñez-Betelu, 1993). If a similar source rock could be proved to exist in West Greenland it would be the first documented occurrence of an oil-prone source rock of this age in the region and would enhance the prospectivity of both offshore southern West Greenland and Melville Bay to the north.

In order to test this possibility the Government of Greenland and the Danish State provided funding for the drilling of the Umiivik-1 borehole on Svartenhuk Halv $\varnothing$ where the oldest known Cretaceous marine sediments in West Greenland are exposed at surface. These comprise mudstones of Coniacian - Santonian age deposited in relatively deep water environments suggesting good possiblities to penetrate the Cenomanian - Turonian succession and to intersect a marine oil-prone source rock.

\section{Setting and stratigraphy}

The West Greenland margin is a rifted continental margin, developed during the opening of the Labrador Sea in the late Mesozoic - early Cenozoic (Chalmers et al., 1993). In response to this break-up a number of rift basins developed along this margin in which a succession of early Cretaceous - Tertiary sediments were deposited (Pedersen \&

\author{
Kevin J. Bate and Flemming G. Christiansen
}

Pulvertaft, 1992; Dam \& Sønderholm, 1994). Onshore exposures of these sediments extend from Svartenhuk Halvø south to Disko (Fig. 1). The outcrops are bounded to the east by a faulted contact with basement which consists of Precambrian gneisses and metasediments (Rosenkrantz \& Pulvertaft, 1969; Pedersen \& Pulvertaft, 1992). The sediments are overlain by Paleocene flood basalts.

Field mapping has identified a NW-SE structural trend in the Svartenhuk Halvø area (Larsen \& Grocott, 1991). On the south-eastern coast of the Umiivik bay the marine Cretaceous sediments dip gently to the south-west but the dip swings slightly to a more westerly direction around Firefjeld. The sediments exposed at surface are predominantly dark grey to black mudstones which are likely to have been deposited in an outer shelf to slope environment. A number of dolerite intrusions can be identified cutting through these sediments in cliff sections.

\section{Recent exploration history}

In 1992 the Geological Survey of Greenland (GGU) drilled five holes on eastern Svartenhuk Halvø as part of a systematic shallow coring project in the Disko - Nuussuaq - Svartenhuk Halvø area (Christiansen, 1993), forming the basis for renewed sedimentological, palynological and organic geochemical studies (Christiansen et al., 1994). The drilling programme was undertaken using a helicopterportable wire-line rig. Total depths of these holes ranged between $66 \mathrm{~m}$ and $86 \mathrm{~m}$.

Prior to the drilling of Umiivik-1, the deepest borehole in the area was GGU shallow borehole 400709 which reached a total depth of $86.24 \mathrm{~m}$ and is situated $15.5 \mathrm{~km}$ to the north-north-west. This borehole intersected the oldest sediments known at that time in the Svartenhuk Halvø area, of Coniacian to Early Santonian age (Nøhr-Hansen, 1994, in press).

During the 1994 field season a seismic programme involving the acquisition of a single refraction and reflection line was carried out along the southern shoreline of Umiivik in collaboration with the seismic consultant Rambøll, Hannemann \& Højlund A/S (Christiansen et al., 1995). A total of $11.5 \mathrm{~km}$ of seismic data was acquired. The seismic line was placed where Santonian marine black mudstones 


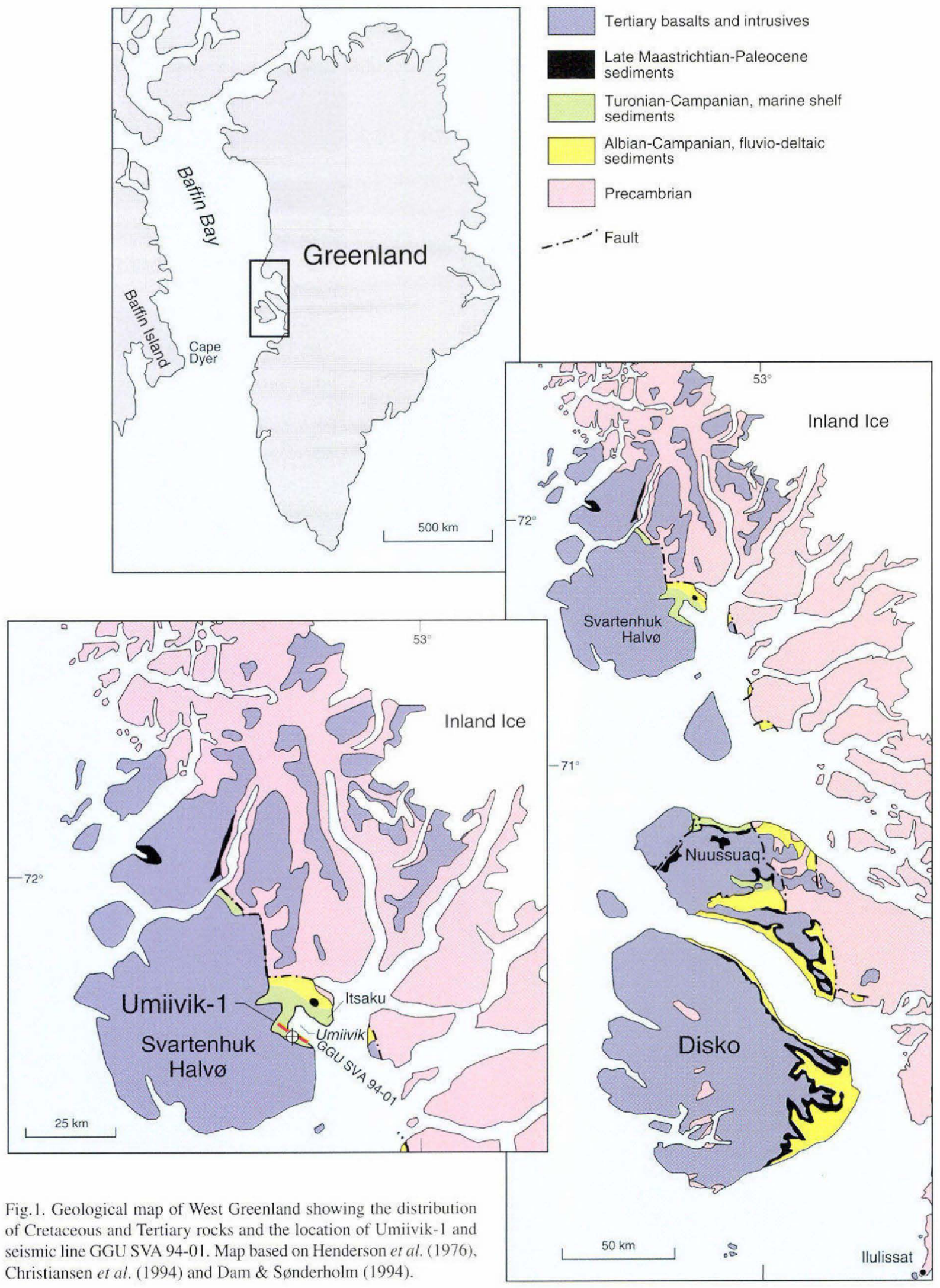




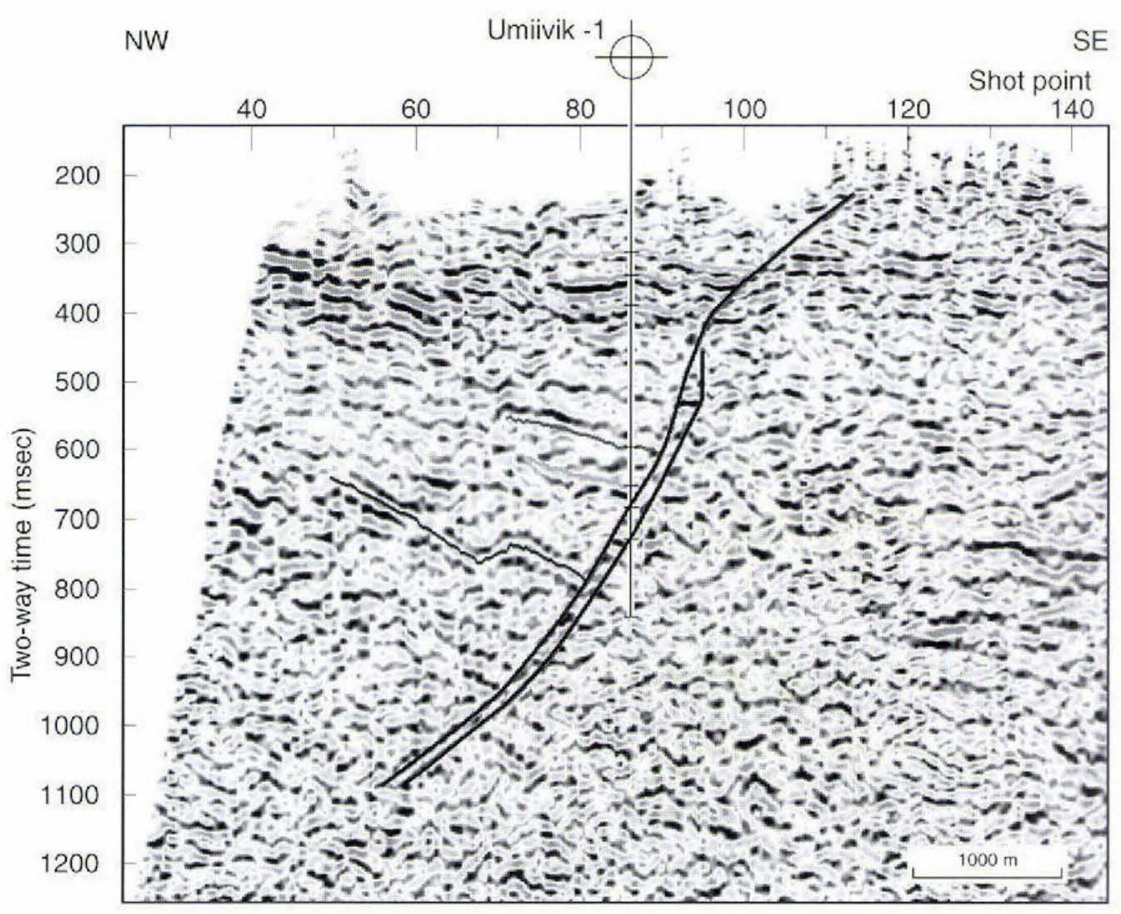

Fig. 2. Part of seismic line GGU SVA94-01 showing interpretation based on drilling results. Solid lines: assumed north-north-west dipping faults. outcrop along the coast. The results of the final processing and initial interpretation did not allow a confident estimate as to the Two Way Time (TWT) to the base of the sedimentary succession; however, it did indicate a weak synclinal attitude to the subsurface geology (Fig. 2). A strong, fairly continuous reflection was seen extending across the entire section between 250 to $400 \mathrm{msec}$ TWT which was interpreted as representing the base of the marine mudstones. The section below this reflector was interpreted as either early Cretaceous fluviatile sandstones similar to those exposed on the north-east side of the Itsaku peninsula $15 \mathrm{~km}$ to the north, or Precambrian basement (Fig. 1). However, the presence of reflectors to a TWT ranging between 800 to $1400 \mathrm{msec}$ makes the latter proposal unlikely. A number of prominent reflectors on the south-eastern end of the line were interpreted to represent Tertiary intrusions, and a diffraction pattern with an origin at shot point (SP) 109 was interpreted to indicate a major fault down throwing to the north-west (Fig. 2).

\section{Drilling of Umiivik-1}

Well Umiivik-1 was drilled by grønArctic Energy Inc. of Calgary, Alberta, Canada as part of a turnkey contract entered into between the Government of Greenland, Minerals Office (Operator) and grønArctic Energy Inc., with the Geological Survey of Denmark and Greenland (GEUS) providing the geological services (see Table 1). The drilling services were provided by Petro Drilling Ltd.

\section{Table 1. Pertinent well data for Umiivik-1}

\section{Well name: Umiivik-1}

Operator: Government of Greenland, Minerals Office turnkey contract with grønArctic Energy Inc., Calgary, Alberta, Canada

Drilling contractor: Petro Drilling Ltd., Halifax, Nova Scotia, Canada

Locality: $\quad$ Svartenhuk Halvø, West Greenland

Co-ordinates: $\quad 71^{\circ} 36^{\prime} 42^{\prime \prime} \mathrm{N}, 54^{\circ} 02^{\prime} 31^{\prime \prime} \mathrm{W}$

Elevation: $\quad \sim 5 \mathrm{~m}$ a.s. 1 .

Well spud date: 21 August 1995

Termination: 13 September 1995

Rig released: $\quad 15$ September 1995

Total Depth: $\quad 1200 \mathrm{~m}, \sim 100 \%$ recovery

Rig type: $\quad$ Longyear fly-in 50 diamond core drill, adapted mining rig

Hole diameter: $\quad 0-148 \mathrm{~m}: 96.0 \mathrm{~mm}$ (HQ rods), 148-1200 m: $75.8 \mathrm{~mm}$ (NQ rods)

Core diameter: $\quad 0-148 \mathrm{~m}: 63.5 \mathrm{~mm}$, 148-1200 m: $47.6 \mathrm{~mm}$

Status: $\quad$ Plugged and abandoned

Main target: Stratigraphic well with the main aim to demonstrate a Cenomanian - Turonian marine source rock for oil

Formation drilled: Upper Cretaceous marine mudstones (1200 m) with occasional Tertiary intrusions

Hydrocarbons: Gas bleeding from core within mudstone sections 


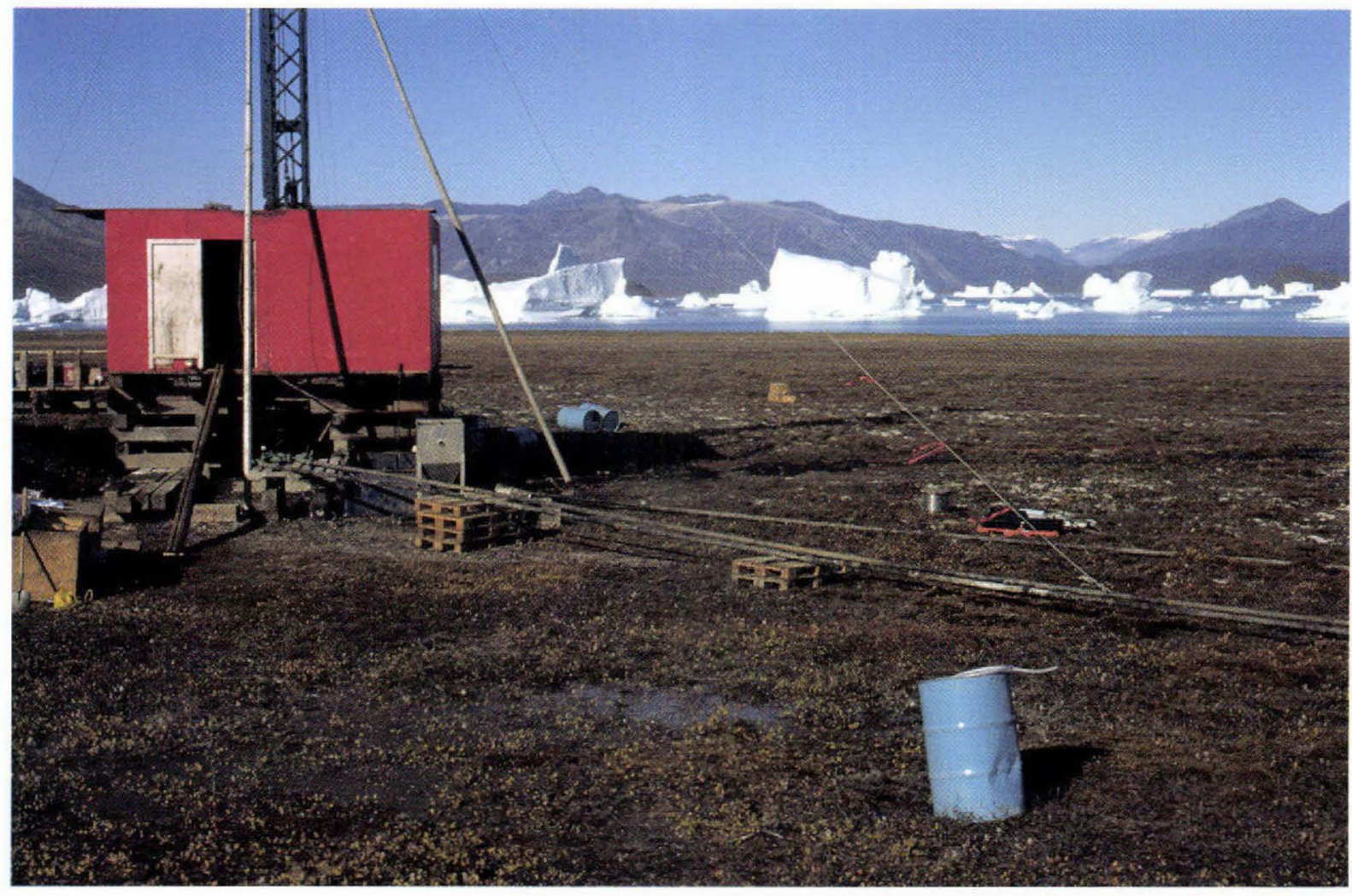

Fig. 3. View of the Longyear wire-line drilling rig at the Umiivik-1 well-site on Svartenhuk Halvø.

of Halifax, Nova Scotia, Canada, using a modified Longyear wire-line drilling rig (Fig. 3; Table 1). The borehole was spudded on 21 August and was terminated at the contract depth of $1200 \mathrm{~m}$ on 13 September, 1995. GEUS was responsible for the well-site geological services which included the preliminary geological description of the core and collection of samples (Bate, 1996). This was followed by detailed analysis in Copenhagen of all samples of core, fluids and gases collected at the wellsite, together with storage of all material taken.

The location of the Umiivik-1 borehole is on the southern coast of Umiivik (Fig. 1) at approximately shot point 86 on seismic line GGU SVA94-01 (Fig. 2). This position facilitated the drilling of a thick sedimentary succession prior to intersection of the presumed large fault interpreted on the seismic data. Further constraints on the positioning of the rig included availability of sufficient water supply, adequate containment facilities and ease of crew changes.

A total of $1200 \mathrm{~m}$ of core was recovered from Umiivik-1 (Fig. 4) with recovery close to $100 \%$. Almost the entire core consists of dark grey, firm and non-calcareous mudstone with abundant silty interbeds. This general lithology was maintained until the contract termination depth (TD) was reached at $1200 \mathrm{~m}$. Such a thick accumulation of mudstone was unexpected and it will require a significant re-evaluation of basin development in the Svartenhuk Halvø area. Based on the preliminary interpretation of the seismic data it had been expected that the well would intersect either non-marine sandstones or basement below a depth of approximately $800 \mathrm{~m}$. The position of the base of the mudstone section now remains conjectural as no obvious basement reflector is evident on the seismic data below the total depth of the hole. A total of nineteen large dolerite intrusions were intersected throughout the well with a cumulative thickness of $238.25 \mathrm{~m}$. These intrusions have raised the local thermal maturity of the mudstones to such a level that little generative potential remains. Similar degradational thermal effects of intrusions on the generative potential of mudstones in the Svartenhuk Halv $\emptyset$ area have been documented by Schiener \& Perregaard (1981). One such intrusion over the depth interval $952 \mathrm{~m}$ to $1027 \mathrm{~m}$ is highly fractured, and resulted in slow penetration and poor core recovery. This heavily fractured intrusion is interpreted as the presumed large fault imaged on the seismic data.

Indications of hydrocarbons were initially encountered at a depth of $245 \mathrm{~m}$ (Fig. 4). Gas escaping from the core was audible (bursting against the aluminium foil in which the core was wrapped). The frequency and rate at which gas was escaping from the core increased with depth and over certain intervals formed a white froth on the surface 

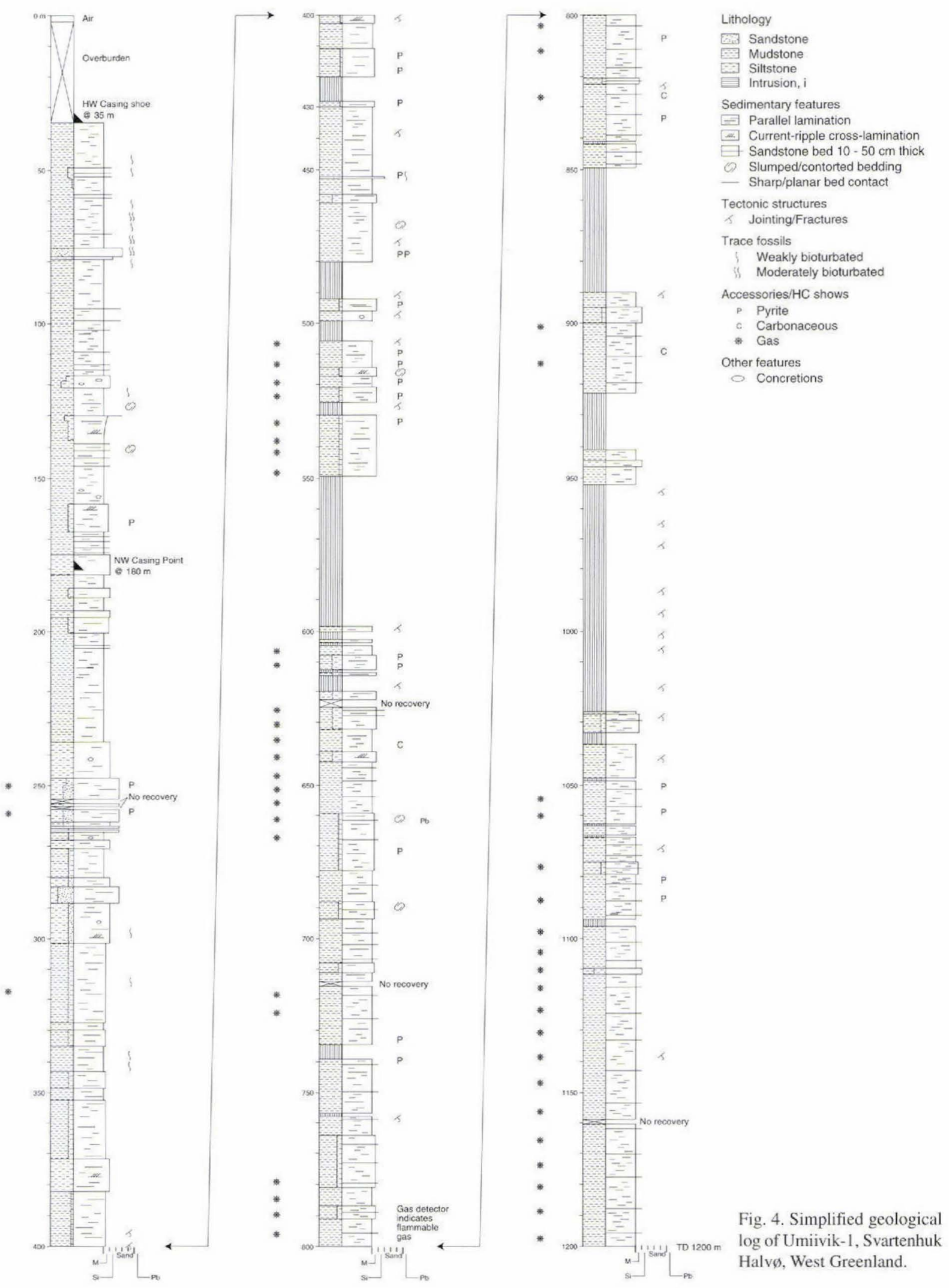
of the core as soon as it was removed from the core barrel. Indications of gas persisted throughout the mudstone sections of the hole, with only the intrusive sections not exhibiting any indications of gas.

The preliminary organic geochemical results show moderate to high (2.5-6.5\%) values of TOC (Total Organic Carbon) throughout the mudstone section. In the uppermost $390 \mathrm{~m}$ of the core in which the sediments are immature ( $\mathrm{T}_{\max }$ below $438^{\circ} \mathrm{C}, \mathrm{R}_{\mathrm{o}}$ below $0.63 \%$ ), the Hydrogen Index values are typically between 75 and 125 suggesting only a minor, if any, potential for oil, but a significant gas potential. In the deeper part of the core, from $405 \mathrm{~m}$ to $1200 \mathrm{~m}$, in which the sediments are post mature $\left(\mathrm{T}_{\max }\right.$ above $500^{\circ} \mathrm{C}$, $\mathrm{R}_{\text {o }}$ above $2.0 \%$ ) Hydrogen Index values are below 35 , in many cases below 5 , and it is not possible to interpret the original generative potential prior to heating by the intrusions.

Head space analyses from tin cans containing the core samples often show very high gas concentrations (more than $50 \%$ hydrocarbons). Most of the gas is relatively dry (mainly methane), but below $750 \mathrm{~m}$, most samples indicate a rather wet gas with high concentrations of ethane and propane and significant amounts of butane and pentane. These data suggest that this mudstone succession, prior to heating from the intrusions, also had a significant generative potential for condensate, perhaps also for oil.

In summary it can be concluded that the results of the drilling of Umiivik-1 have demonstrated a much greater thickness of mudstone than was predicted from the seismic data. In general the organic richness of the mudstones is moderate to high but the sediments have been thermally degraded by intrusions to such an extent that they are postmature for oil generation. A well drilled through similar mudstones but without intersecting any large intrusions might produce more encouraging results as to the prospectivity of the Svartenhuk Halvø area.

Acknowledgements. Funding for the drilling project was provided from the Government of Greenland, Minerals Office and the Danish State through the Mineral Resources Administration for Greenland. The drilling programme was completed in collaboration with two Canadian companies: grønArctic Energy Inc. and Petro Drilling Ltd. Greenland Air provided helicopter support for the duration of the project and Dykkerselskabet provided the support vessel Viking Naja. In particular thanks are due to Cam Hanna of grønArctic Energy Inc. for good planning and technical support.

\section{References}

Bate, K. J. 1996: Well summary Umiivik-1, Svartenhuk Halvø, West Greenland. Geological Survey of Denmark and Greenland, Report 1996/27, 24 pp.

Chalmers, J. A., Pulvertaft, T. C. R., Christiansen, F. G., Larsen, H. C., Laursen, K. H. \& Ottesen, T. G. 1993: The southern West Greenland continental margin: rifting history, basin development and petroleum potential. In Parker, J. R. (ed.) Petroleum geology of Northwest Europe: Proceedings of the 4th Conference, 915-931. London: Geological Society.

Christiansen, F. G. 1993: Disko Bugt Project 1992, West Greenland. Rapp. Gronlands geol. Unders. 159, 47-52.

Christiansen, F. G., Dam, G., Nøhr-Hansen, H. \& Sønderholm, M. 1994: Shallow core drilling summary sheets: Cretaceous sediments of Nuussuaq and Svartenhuk Halvø (GGU 400701 - 400712). Open File Ser. Grønlands geol. Unders. 94/10, $31 \mathrm{pp}$.

Christiansen, F. G., Marcussen, C. \& Chalmers, J. A. 1995: Geophysical and petroleum geological activities in the NuussuaqSvartenhuk Halvø area 1994: promising results for onshore exploration potential. Rapp. Gronlands geol. Unders. 165, 30-39.

Dam, G. \& Sønderholm, M. 1994: Lowstand slope channels of the Itilli succession (Maastrichtian - Lower Paleocene), Nuussuaq, West Greenland. Sed. Geol. 94, 47-71.

Larsen, J. G. \& Grocott, J. 1991: Geologisk kort over Grønland, 1:100 000 Svartenhuk 71 V.1 N. Copenhagen: Geol. Survey of Greenland.

Nøhr-Hansen, H. 1994: Dinoflagellate cyst biostratigraphy of the Upper Cretaceous black mudstones in Svartenhuk Halvø, West Greenland. Open File Ser. Gronlands geol. Unders. 94/9, 25 pp.

Nøhr-Hansen, $H$. in press: Upper Cretaceous dinoflagellate cyst stratigraphy, onshore West Greenland. Bull. Grønlands geol. Unders. 170, 104 pp.

Núñez-Betelu, L. K. 1993: Rock-eval/TOC pyrolysis data from the Kanguk formation (Upper Cretaceous), Axel Heiberg and Ellesmere Islands, Canadian Arctic. Open File Rep. Geol. Survey Canada $2727,29 \mathrm{pp}$.

Pedersen, G. K. \& Pulvertaft T. C. R. 1992: The non-marine Cretaceous of the West Greenland Basin, onshore West Greenland. Cretaceous Res. 13, 263-272.

Rosenkrantz, A. \& Pulvertaft T. C. R. 1969: Cretaceous - Tertiary stratigraphy and tectonics in northem West Greenland. Bull. Amer. Ass. Petrol. Geol. 12, 883-898.

Schiener, E. J. \& Perregaard, J. 1981: Thermal maturation of organic matter by a thick basaltic sill in Upper Cretaceous shales, Svartenhuk Halvø, central West Greenland. Rapp. Grønlands geol. Unders. 102, $16 \mathrm{pp}$.

K. J. B., Geological Survey of Denmark and Greenland, Copenhagen. Present address: Robertson Research International Ltd, Llanhros, Llandudno, LL30 1SA, U.K.

F. G. C., Geological Survey of Denmark and Greenland, Copenhagen 